\title{
Exocrine Pancreatic Function after Upper Abdominal Surgery
}

\author{
Yasuo Suda,* Mitsuyasu Shiraso $\dagger$ and Toshio Sato \\ First Department of Surgery, Tohoku University School \\ of Medicine, Sendai
}

Stda, Y., ShIraso, M. and Sato, T. Exocrine Pancreatic Function after Upper Abdominal Surgery. Tohoku J. exp. Med., 1975, 115 (4), 307-317 Daily pancreatic flow and daily outputs of bicarbonate and amylase in pure pancreatic juice were observed in 15 postoperative patients who underwent upper abdominal surgery. Exocrine pancreatic secretion under the stimulation by endogenous or exogenous hormones was well correlated with the extent of pancreatic fibrosis estimated by the histometrical treatment. Exocrine pancreatic secretion in Billroth II type of gastrectomy was depressed to $60-70 \%$ of the patients' with Billroth I type of gastrectomy. In distal pancreatectomy the depression in the exocrine pancreatic secretion almost corresponded with the resected volume of pancreas. Exocrine pancreatic secretion in pancreatodoudenectomy was highly depressed beyond the expected value from the resected volume and fibrosis of the pancreas. This was interpreted as partly due to the elimination of hormonal mechanism by duodenectomy and partly due to the denervation of the secretory fibers by surgical manipulation. —— exocrine pancreatic secretion; pancreatic fibrosis; pancreatoduodenectomy; distal pancreatectomy; gastrectomy

Although many studies have been performed on the physiology or pathophysiology of exocrine function of pancreas, most of them were animal experiments or carried out on patients with morbid pancreatic fistulae encountered during the postoperative period. The present study deals with the comparison of the exocrine functions in patients who underwent upper abdominal surgery of several types with the external pancreatic duct drainage. The effects of pancreatic or gastric resection and pancreatic fibrosis on the exocrine pancreatic function were investigated by the histometrical treatment of the tissue and the quantitative measurement of pure pancreatic juice.

\section{Materials and Methods}

The control cases were tabulated in Table 1. Pancreatic and hepatic functions in these cases were proved to be within normal limits by pancreozymin-secretin test and routine liver function tests performed preoperatively. The other cases studied were tabulated in Tables 2 and 3. The effect of pancreatic fibrosis on the exocrine secretion was investigated in Case 5. The influence of duodenal passage of gastric content upon the exocrine secre-

Received for publication, December 5, 1974.

* Present address: Dept. of Surg., National Sendai Hospital, 2-8-8, Miyagino, Sendai 983.

† Present address: Surgical Clinic, Mito Kyodo Hospital, 3-2-7, Miyamachi, Mito 310. 
TABLE 1. Control cases

\begin{tabular}{|c|c|c|c|}
\hline Case & Age \& sex & Diagnosis & Operation performed \\
\hline 1 & 61 今 & Cholecystocholedocholithiasis & $\begin{array}{l}\text { Cholecystectomy, choledocholitho- } \\
\text { tomy, T-tube drainage }\end{array}$ \\
\hline 2 & 55우 & Cholecystolithiasis & Cholecystectomy, T-tube drainage \\
\hline 3 & 55 우 & Intrahepatic gallstone & $\begin{array}{l}\text { Cholecystectomy, partial hepatec- } \\
\text { tomy, T-tube drainage }\end{array}$ \\
\hline 4 & 30 今 & Hepaticolithiasis & $\begin{array}{l}\text { Cholecystectomy, choledocholitho- } \\
\text { tomy, T-tube drainage }\end{array}$ \\
\hline
\end{tabular}

TABLE 2. Cases of pancreatic fibrosis and gastrectomies

\begin{tabular}{|c|c|c|c|}
\hline Case & Age \& sex & Diagnosis & Operation performed \\
\hline 5 & 52 우 & $\begin{array}{l}\text { Cholecystolithiasis, chronic } \\
\text { pancreatitis }\end{array}$ & Cholecystectomy, T-tube drainage \\
\hline 6 & $51 \hat{s}$ & Gastric cancer & B I gastrectomy \\
\hline 7 & 26 今 & $\begin{array}{l}\text { Membranous mucosal folding } \\
\text { of duodenum }\end{array}$ & B II gastrectomy, cholecystec- \\
\hline 8 & $39 \hat{o}$ & Gastric cancer & $\begin{array}{l}\text { Total gastrectomy, jejunal inter- } \\
\text { position }\end{array}$ \\
\hline 9 & $43 \hat{\delta}$ & Gastric cancer & $\begin{array}{l}\text { Total gastrectomy, esophagoje- } \\
\text { junostomy Roux en Y }\end{array}$ \\
\hline 10 & 50 古 & Gastric cancer & $\begin{array}{l}\text { Total gastrectomy, esophagoje- } \\
\text { junostomy, distal pancreatec- } \\
\text { tomy }\end{array}$ \\
\hline
\end{tabular}

TABLE 3. Cases of pancreatoduodenectomy

\begin{tabular}{ccll}
\hline Case & Age \& sex & \multicolumn{1}{c}{ Diagnosis } & Operation performed \\
\hline 11 & $44 \hat{\delta}$ & $\begin{array}{l}\text { Localized pancreatitis of the } \\
\text { head of pancreas } \\
\text { Insulinoma of the head of } \\
\text { pancreas }\end{array}$ & Pancreatoduodenectomy \\
12 & 51 Same as above \\
13 & $64 \hat{\delta}$ & $\begin{array}{l}\text { Cancer of common bile duct } \\
\text { Same as above } \\
\text { Cancer of the head of pan- } \\
\text { creas }\end{array}$ & $\begin{array}{l}\text { Same as above } \\
\text { Same as above } \\
\text { Same as above }\end{array}$ \\
\hline
\end{tabular}

tion was studied in Cases 6, 7, 8 and 9. The effect of distal pancreatic resection on the exocrine pancreatic secretion was examined in Case 10 using Case 9 as control, and that of proximal pancreatic resection was examined in Cases 11 to 15 , taking into consideration the fibrotic change of the remnant pancreata.

After transduodenal minor sphineterotomy, pancreatic duct drainage was exteriorized through the jejunal loop with a polyethylene tube of $2 \mathrm{~mm}$ in caliber.

Pancreatic juice was collected every $6 \mathrm{hr}$ into a bottle in an ice bucket. Checking its volume at the bedside, bicarbonate and amylase concentrations were measured for an aliquot according to the methods of Van Slyke et al. (1919) and Caraway (1959) and expressed as total dialy output, i.e. the sum of 4 six-hr outputs. The average daily output on the 7th to 14th postoperative day was used for the purpose of comparison, since the patients recovered so as to have ordinary meals on the 7 th to 10 th postoperative day. For the purpose of exogenous stimulation, secretin of $0.02 \mathrm{unit} / \mathrm{min} / \mathrm{kg}$ was infused and pancreozymin of 1 unit $/ \mathrm{kg}$ was administered by a single injection after the pancreatic 


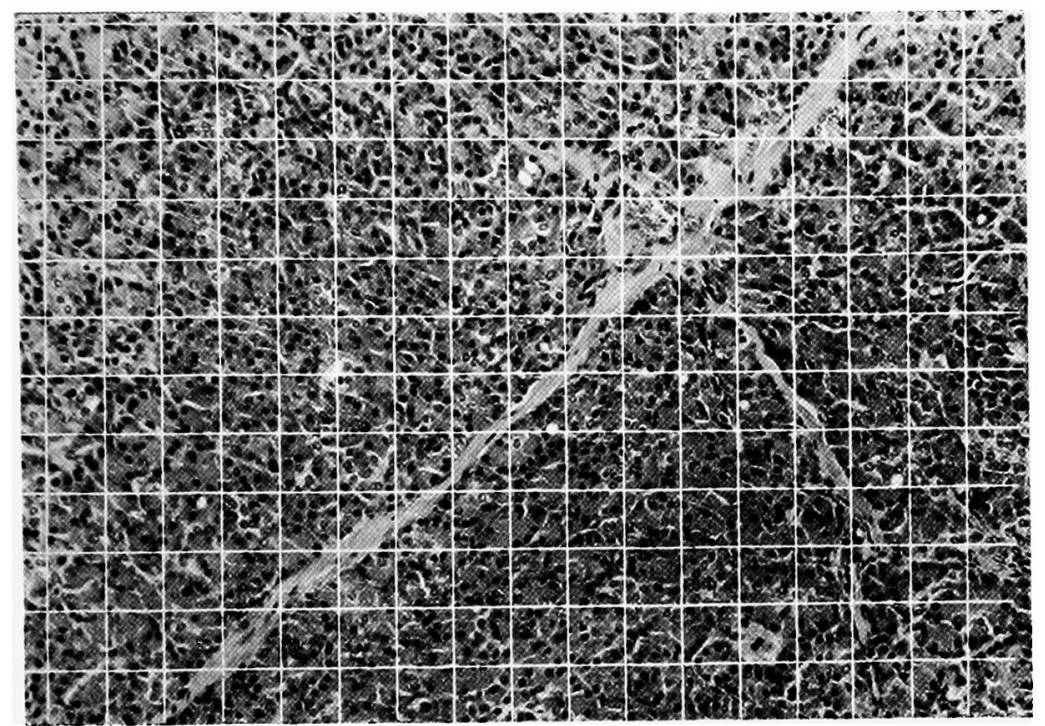

Fig. 1. Point counting method. Intra-acinar and interacinar connective tissue overlapping with the crossings of micrometer was counted. The parenchymal ratio was expressed as a quotient of the parenchymal points by the total crossings. Photo shows the histology of Case 10 with the parenchymal ratio $94.24 \%$.

flow of a few consecutive collections reached plateau. As the parameters for the comparison of exocrine pancreatic function, the above-mentioned flow rate, bicarbonate output and amylase output are used in the following description.

The histological examination was performed in the specimen from the cut-surface and mid-portion of the resected pancreas by hematoxylin-eosin stain and Masson's trichrome stain. In the case whose pancreas was not operated, the specimen of wedge resection from the head of pancreas was used instead. The point counting method (Weibel et al. 1966) was applied to investigate the parenchymal ratio in the tissue. As shown in Fig. 1, a glass disc incising $21 \times 21$ crossings of lattice was equipped under the ocular lens of microscope. Including the small vessels and intra-acinar connective tissue, non-parenchymal portion overlapping with the crossings of micrometer was counted in randomized 50 views, i.e. $21 \times 21 \times 50$ points, as a whole, on the histology slide. Parenchymal ratio was then expressed as a quotient of the parenchymal points over total crossings.

In 15 microscopically normal pancreata the parenchymal ratio was calculated histometrically, the obtained value being $92.77 \pm 1.31 \%$. It was postulated that pancreas with normal histology had its parenchyma of approximately over $90 \%$ in its tissue.

In usual pancreatoduodenectomy, pancreas is resected on the left side of the superior mesenteric vessels. The cadaver pancreata with normal histology in a middle age were weighed by separating the head portion from the body and tail as usual pancreatoduodenectomy. The average weights of both in 21 cadaver pancreata were $35.00 \pm 10.15 \mathrm{~g}$ in cephalic portion and $38.09 \pm 10.88 \mathrm{~g}$ in caudal portion. Thus, the weight ratio of cephalic to caudal pancreas under ordinary pancreatoduodenectomy was approximately $1: 1$. In distal pancreatectomy often combined with total or proximal gastrectomy for cancer, the pancreas is usually resected at the stem of the splenic artery to dissect the regional lymph nodes along the splenic artery. The mean weights of cadaver pancreata transected at this line were $38.54 \pm 10.22 \mathrm{~g}$ in cephalic portion and $24.45 \pm 7.48 \mathrm{~g}$ in caudal portion, showing the approximate ratio of $3: 2$. Thus, $40 \%$ of the total organ is resected and the remaining $60 \%$ would be preserved in this distal pancreatectomy. 


\section{Results}

Daily secretion in normal and fibrotic pancreata

Daily flow of pancreatic juice in controls with normal histology ranged from 833.9 to $958.5 \mathrm{ml}$, the average value being $891.6 \mathrm{ml}$ (Table 4). Daily bicarbonate output ranged from 79.45 to $93.63 \mathrm{mEq}$ with the average of $85.79 \mathrm{mEq}$. Daily amylase output was 25323 units on the average. Pancreatic parenchyma in 4 controls occupied from 90.47 to $93.96 \%$ (mean; $92.58 \%$ ) of the total tissue. In contrast, daily flow of pancreatic juice and daily outputs of bicarbonate and amylase in Case 5 were $587.7 \mathrm{ml}, 59.75 \mathrm{mEq}$ and 15682 units, respectively. The histology of Case 5 was shown in Fig. 2. The histometrical ratio of this tissue was $70.95 \%$ of parenchyma. Since the mean control parenchymal ratio in this series was $92.58 \%$, the parenchymal reduction in Case 5 was corrected to $70.95 / 92.58$ or $76.63 \%$. Comparing the parameters of secretory function in Case 5 with control, the extents of reduction in daily flow and daily outputs of bicarbonate and amylase were $65.9 \%, 69.6 \%$ and $61.9 \%$, respectively. Although these values did not

TABLE 4. Exocrine pancreatic secretion in controls and pancreatic fibrosis

\begin{tabular}{ccccc}
\hline Case & $\begin{array}{c}\text { Flow } \\
(\mathrm{ml} / \text { day })\end{array}$ & $\begin{array}{c}\text { Bicarbonate } \\
(\mathrm{mEq} / \text { day) }\end{array}$ & $\begin{array}{c}\text { Amylase } \\
\text { (units/day) }\end{array}$ & $\begin{array}{c}\text { Parenchymal ratio } \\
(\%)\end{array}$ \\
\hline 1 & 958.5 & 86.059 & 28351.3 & 93.70 \\
2 & 928.9 & 84.059 & 23419.9 & 92.19 \\
3 & 845.2 & 93.634 & 24458.0 & 90.47 \\
4 & 833.9 & 79.450 & 25062.4 & 93.96 \\
Mean & 891.6 & 85.790 & 25322.9 & 92.58 \\
\hline 5 & 587.7 & 59.746 & 15682.7 & 70.95 \\
\hline
\end{tabular}

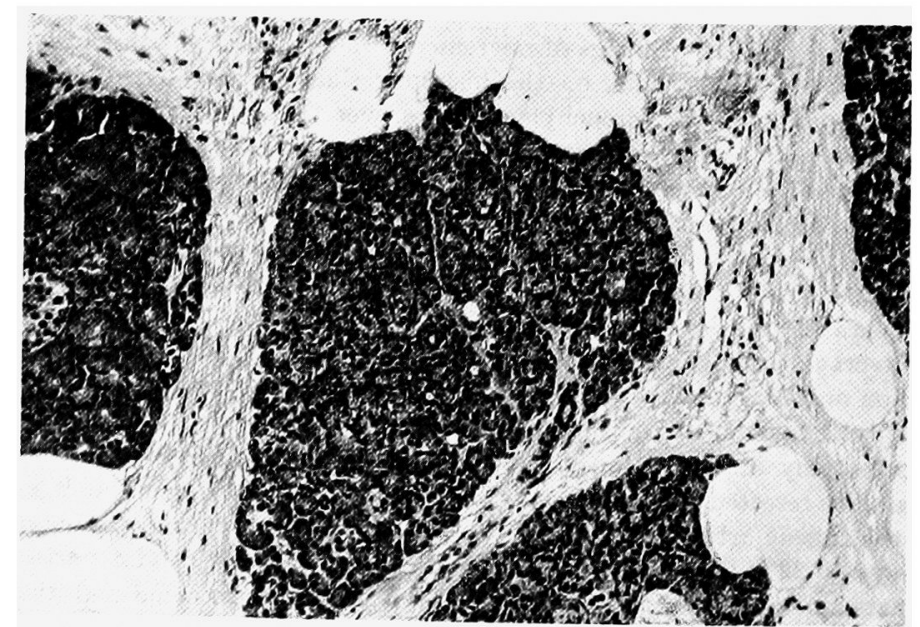

Fig. 2. Histology of Case 5. Parenchymal ratio was estimated at $\mathbf{7 0 . 9 5 \%}$. 
exactly coincide with the degree of reduction in parenchyma of $76.6 \%$, the above three parameters were depressed at a similar rate.

\section{Daily pancreatic secretion after gastric resection}

The parameters of pancreatic exocrine function in the cases of gastric resection were shown in Table 5. Case 6 underwent gastric resection with gastroduodenostomy (Billroth I) for gastric cancer and Case 7 underwent the same with gastrojejunostomy for the membranous mucosal folding at the 2nd portion of duodenum. Histological investigation of pancreas was not performed in Case 6, but the gross finding was normal in appearance and consistency at the time of operation. In comparison with the control values, daily output of bicarbonate in Case 6 was slightly decreased at a rate of $88.9 \%$ but daily flow and daily output of amylase in this case remained in the control range at the rates of $97.7 \%$ and $91.2 \%$, respectively. Comparing the three parameters of Case 6 (Billroth I gastrectomy) with those of Case 7 (Billroth II gastrectomy), all parameters in Case 7 were depressed at the similar rates, i.e., $65 \%$ in flow, $66 \%$ in bicarbonate and $68 \%$ in enzyme outputs. By the comparison of these two cases, it was suggested that there might be a difference in postoperative exocrine pancreatic function between Billroth I gastrectomy and Billroth II, that is, between duodenal passage and diversion; the secretion was depressed to 60 to $70 \%$ in the latter.

TABLE 5. Exocrine pancreatic secretion in gastrectomies

\begin{tabular}{rcccc}
\hline Case & $\begin{array}{c}\text { Flow } \\
(\mathrm{ml} / \text { day) }\end{array}$ & $\begin{array}{c}\text { Bicarbonate } \\
\text { (mEq/day) }\end{array}$ & $\begin{array}{c}\text { Amylase } \\
\text { (units/day) }\end{array}$ & $\begin{array}{c}\text { Parenchymal ratio } \\
(\%)\end{array}$ \\
\hline 6 & 871.2 & 76.227 & 23104 & $*$ \\
7 & 567.9 & 50.605 & 15854 & 93.93 \\
8 & 875.8 & 47.997 & 14480 & $*$ \\
9 & 581.3 & 32.981 & 7655 & 90.76 \\
10 & 376.5 & 18.378 & 4949 & 94.24 \\
\hline
\end{tabular}

* No specimen for histology. Gross finding was normal.

Similar comparison was made between Cases 8 and 9 in total gastrectomy. The alimentary tract after total gastrectomy was reconstructed by jejunal substitution for stomach in Case 8 and by esophagojejunostomy combined with Roux en $\mathrm{Y}$ jejunojejunostomy in Case 9. Namely, the duodenal passage was preserved in Case 8 but diverted in Case 9 . The value of daily pancreatic flow under total gastrectomy with jejunal interposition was similar to control, showing $98.23 \%$ of the control value. The bicarbonate and enzyme outputs, however, showed a considerable depression to $55.9 \%$ and $57.2 \%$ of controls, respectively. As compared with Case 8 , Case 9 showed a depressed daily flow to $66.3 \%$. This seemed to be due to the diversion of duodenal passage in Case 9. The declines in bicarbonate and enzyme outputs were $68.7 \%$ and $52.8 \%$, respectively. The decrease of $66 \%$ and $69 \%$ in flow and bicarbonate output under total gastrectomy was almost the same as under subtotal gastrectomy, but the enzyme output was less than the latter. 


\section{Daily pancreatic secretion after pancreatectomy}

On the assumption that $60 \%$ of pancreas was preserved in distal pancreatectomy at the stem of the lienal artery, comparison was made between the cases of total gastrectomy with and without distal pancreatectomy (Table 5). In Cases 9 and 10, the alimentary tracts were reconstructed by esophagojejunostomy and Roux en $\mathrm{Y}$ jejunojejunostomy. The former was combined with distal pancreatectomy, but the latter was not. The parenchymal ratios in both cases were within normal range histometrically. The exocrine parameters of Case 10 showed the decrease of $64.76 \%$ in pancreatic flow, $55.72 \%$ in bicarbonate output and $64.66 \%$ in enzyme output against the respective values of Case 9. These corresponded approximately with the ratio of preserved remnant parenchymata.

In ordinary pancreatoduodenectomy as prescribed before, $50 \%$ of pancreas parenchyma was preserved. The histology of the pancreatic cut-surface in pancreatoduodenectomy varied with the fibrotic changes for the lesion of the pancreatic head, and the parenchymal ratio ranged from $91.53 \%$ to only $2.07 \%$. The parameters of pancreatic exocrine function in 5 pancreatoduodenectomized cases were shown in Table 6 in an ascending order of fibrosis. Case 11 had localized cephalic pancreatitis which was misjudged as carcinoma. The histology of the resected surface was normal and its parenchymal ratio was estimated at $91.53 \%$.

TABLE 6. Exocrine pancreatic secretion in pancreatoduodenectomy

\begin{tabular}{cccccc}
\hline Case & $\begin{array}{c}\text { Flow } \\
(\mathrm{ml} / \text { day })\end{array}$ & $\begin{array}{c}\text { Bicarbonate } \\
(\mathrm{mEq} / \text { day) }\end{array}$ & $\begin{array}{c}\text { Amylase } \\
\text { (units/day) }\end{array}$ & $\begin{array}{c}\text { Parenchymal } \\
\text { ratio (\%) }\end{array}$ & $\begin{array}{c}\text { Ratio to } \\
\text { Case 11 }\end{array}$ \\
\hline 11 & 282.3 & 16.375 & 2858 & 91.52 & - \\
12 & 233.9 & 11.894 & 2317 & 82.84 & 90.52 \\
13 & 275.5 & 10.730 & 2405 & 78.50 & 85.77 \\
14 & 93.1 & 4.544 & 1566 & 36.11 & 39.46 \\
15 & 34.6 & 2.011 & 83 & 2.07 & 2.26 \\
\hline
\end{tabular}

Comparison of the exocrine parameters was made between the pancreatoduodenectomized Case 11 with normal histology and the unresected controls. The values of the former were $31.66 \%$ of the controls in flow, $19.08 \%$ in bicarbonate output and $11.26 \%$ in enzyme output.

Applied Case 11 as the pancreatoduodenectomized control, each exocrine parameter in Case 12 with parenchymal ratio of $82.84 \%$ (corrected ratio to Case 11 ; $90.52 \%$ ) was depressed in an almost parallel fashion, that is, to $82.8 \%$ in flow, $72.6 \%$ in bicarbonate output and $81.1 \%$ in enzyme output. The data of Case 13 were not exactly comparable with others', since the averages during the 5th to the 10th postoperative day were adopted because of the spontaneous removal of pancreatic duct drainage on the 12th postoperative day. The same comparison was attempted between Case 13 with $85.8 \%$ of the corrected parenchymal ratio and Case 11 with the normal histology. The declined ratios were $97.6 \%$ in flow, 
$65.5 \%$ in bicarbonate output and $84.1 \%$ in enzyme output. These did not correspond with the histological parenchymal ratio except for the enzyme output. The depression rates of parameters in Case 14 with $39.46 \%$ of the parenchymal ratio were $32.9 \%$ in flow, $27.8 \%$ in bicarbonate and $54.8 \%$ in enzyme outputs, respectively. In Case 15 of almast complete fibrotic replacement, flow and bicarbonate output were markedly decreased, but as compared with the parenchymal ratio of $2.26 \%$ these values were as big as 4 times. On the other hand, the enzyme output of this case was depressed to a similar degree to the parenchymal ratio.

\section{Estimated mean concentrations of bicarbonate and amylase}

Mean bicarbonate and amylase concentrations in each case were estimated from the values on the above-mentioned postoperative days. Mean daily bicarbonate concentration in 4 controls ranged from 89.9 to $110.8 \mathrm{mEq} /$ liter, averaging $96.22 \mathrm{mEq} /$ liter. Mean daily amylase concentration in the controls ranged 2521 to 3005 units $/ 100 \mathrm{ml}$, averaging 2840.1 units $/ 100 \mathrm{ml}$. Mean bicarbonate and amylase concentrations in Case 5 with the corrected parencymal ratio of $76.63 \%$ were within the control range. In subtotal gastrectomy with Billroth I or II anastomosis, mean bicarbonate concentration was 90 or $92 \%$ of the control and mean amylase concentration was 93 or $98 \%$. In total gastrectomy with jejunal interposition or Roux en $\mathrm{Y}$ anastomosis, mean bicarbonate concentration was 56 or $58 \%$ of the control and amylase concentration was 58 or $46 \%$. So far as the mean bicarbonate and amylase concentrations were concerned, it was assumed that in subtotal or total gastrectomy, these concentrations were influenced by the degree of gastric resection, but not so much affected by the mechanical duodenal passage under the ordinary intake of diet. The difference in mean concentration from the daily amylase output, therefore, seemed to be due to the presence or absence of stomach, or surgical manipulation such as denervation of the secretory fibers.

From the comparison between Cases 9 and 10 on which distal pancreatectomy was performed, no distinguished difference was observed. Mean bicarbonate concentration in pancreatoduodenectomy ranged from 38.95 to $58.12 \mathrm{mEq}$ /liter, averaging $50.95 \mathrm{mEq} /$ liter. These values accounted for 40 to $60 \%$ decrease against the control, but no clear-cut correlation with the fibrotic change of remnant pancreata. Decrease in mean amylase concentration ranged from 35 to $6 \%$, and the lower the parenchymal ratio, the less the amylase concentration was.

\section{Secretory responses to exogenous secretin and pancreozymin}

The above-described data were on the secretory responses to so-called endogenous stimulation of diet. Responses to the exogenous stimulants were as shown in Table 7. Bicarbonate concentration under the secretin infusion was increased up to 115 to $200 \%$, as compared with the unstimulated values. Flow of pancreatic juice in the fibrotic pancreas under secretin infusion was lower than control. Similar results on bicarbonate concentration were obtained in the fibrotic 
TABLE 7. Exocrine pancreatic secretion under exogenous stimulations

\begin{tabular}{|c|c|c|c|c|c|c|c|}
\hline \multirow[b]{2}{*}{ Caso } & \multicolumn{3}{|c|}{ Secretin infusion } & \multicolumn{2}{|c|}{$\begin{array}{l}\text { Pancreozymin } \\
\text { stimulation }\end{array}$} & \multirow{2}{*}{$\begin{array}{c}\text { Parenchy- } \\
\text { mal ratio } \\
(\%)\end{array}$} & \multirow{2}{*}{$\begin{array}{c}\text { Decrease } \\
\text { ratio to } \\
\text { controls } \\
(\%)\end{array}$} \\
\hline & $\begin{array}{c}\text { Flow } \\
(\mathrm{ml} / 10 \mathrm{~min})\end{array}$ & $\begin{array}{l}\text { Bicarbonate } \\
(\mathrm{mEq} / \\
10 \mathrm{~min})\end{array}$ & $\begin{array}{c}\text { Amylase } \\
\text { (units/ } \\
10 \mathrm{~min} \text { ) }\end{array}$ & $\begin{array}{c}\text { Amylase } \\
\text { (units/ } \\
10 \mathrm{~min} \text { ) }\end{array}$ & $\begin{array}{c}\text { Increase } \\
\text { ratio } \\
(\%)\end{array}$ & & \\
\hline 4 & 21.7 & 2.381 & 194.30 & 336.6 & 173.2 & 92.19 & 99.37 \\
\hline 5 & 10.9 & 1.429 & 93.33 & 227.6 & 158.8 & 70.95 & 76.48 \\
\hline 6 & 23.0 & 2.782 & 222.58 & 380.2 & 170.8 & * & - \\
\hline 14 & 6.9 & 0.688 & 21.80 & 23.9 & 109.9 & 36.11 & 38.92 \\
\hline 15 & 1.0 & 0.062 & 4.19 & 5.7 & 136.3 & 2.07 & 2.23 \\
\hline $\begin{array}{l}\text { Mean of } \\
\text { normals } \\
(N=18)\end{array}$ & $\begin{array}{l}22.87 \\
\pm 6.03\end{array}$ & $\begin{array}{l}2.590 \\
\quad \pm 0.760\end{array}$ & $\begin{array}{l}181.50 \\
\quad \pm 57.29\end{array}$ & & & $\begin{array}{l}92.77 \\
\quad \pm 1.31\end{array}$ & 100 \\
\hline
\end{tabular}

* No specimen for histology. Gross finding of pancreas was normal.

pancreas remnant under pancreatoduodenectomy. In Case 5 with $76.6 \%$ of the corrected parenchymal ratio, however, the change in bicarbonate concentration was minimal.

The ratio of percent increase in amylase concentration under pancreozymin stimulation was 110 to $160 \%$ in the present series. On the other hand, the ratios in flow of juice and bicarbonate concentration were around $110 \%$. Compared with each amylase concentration in the cases studied under pancreozymin stimulation, the percent increase after stimulation was correlated with fibrotic replacement. It was concluded, therefore, that the changes in water and enzyme secretion seemed to be correlated with the pancreatic fibrosis, even under these corresponding hormonal stimulations.

\section{Discussion}

Early postoperative exocrine pancreatic function after upper abdominal surgery was studied by White and co-workers (Elmslie et al. 1964; Tournut and White 1972). Daily flow of pancreatic juice is not constant in the literature, ranging from 700 to $4000 \mathrm{ml}$. The flow in the controls with normal pancreatic ductography and histology was 830 to $958 \mathrm{ml}$ a day in the present study, which was comparable with the value of Tournut and White (1972). As reported previously by one of the present authors (Shiraso 1973), a gradual increase in pancreatic secretion was observed in the early convalescent period after surgery. But the pancreatic flow and the concentrations of bicarbonate and enzyme showed constant values after the 7 th to 10th postoperative day. Therefore, the values for one to two weeks after surgery were available for the present comparative study. Duodenal passage of gastric content is considered to liberate endogenous stimulants to pancreas. In comparison of different anastomotic types after subtotal or total gastrectomy, cases of diverted duodenum showed 60 to $70 \%$ depression in pancreatic secretion. Clinically, better nutritional absorption in Billroth I 
gastrectomy than in Billroth II was also reported in the postoperative balance study (MacLean et al. 1954; Kaneko 1971). Annis and Hallenbeck (1952) reported from their animal experiments of Billroth I and II gastrectomy, that a clear difference was noticed by dietary stimulation, though the exocrine change was not observed after secretin stimulation or duodenal acidification. White et al. (1963) showed that the duodenal response to the exogenous stimulants was depressed by about $30 \%$ in Billroth I patients and by about $60 \%$ in Billroth II patients as compared with the normal. Placing a suction tube at the papilla of Vater, however, no considerable difference in duodenal aspirate was noticed between Billroth I and II gastrectomies. They suggested, therefore, that it might be due to the absorption of enzyme in the duodenal loop (Lenninger et al. 1965). From the results of the present study, the difference in secretory response between Billroth I and II gastrectomies was considered more likely due to the lack in the endogenous duodenal stimulation caused by the diversion of gastric contents.

In order to investigate the exocrine function after pancreatoduodenectomy, two major factors, i.e. the volume of resected pancreas and the eliminated duodenal loop, should be taken into consideration. The volume of resected pancreas in ordinary pancreatoduodenectomy was roughly estimated as $50 \%$ of the total organ. Assuming the effect of the duodenal diversion as 60 to $70 \%$ decrease in pancreatic secretion of the control, the remnant pancreas without fibrotic change in pancreatoduodenectomy would secrete 30 to $35 \%$ of the control. In the present series of pancreatoduodenectomy, the secretory depressions in the pancreatic remnant without fibrosis were $31.7 \%$ in pancreatic flow, $19.1 \%$ in bicarbonate and $11.3 \%$ in enzyme output against the control. Namely, the pancreatic flow corresponded to the expected estimation, but the outputs of bicarbonate and enzyme were lower than the expected values. Several factors such as the lack of endogenous stimulation for duodenectomy, upper jejunal diversion for pancreatojejunostomy and exchange mechanism (Janowitz and Dreiling 1962) for the depressed pancreatic flow would contribute to the secretory depression.

The secretory changes in distal pancreatectomy were examined in two cases of total gastrectomy with the same reconstructive anastomosis. Their decreases were almost the same as the parenchymal reduction of $40 \%$.

The correlation between function and histological changes in the corresponding gland has been generally accepted and the exocrine function in experimentally produced pancreatic lesion has been studied by many investigators (Wang et al. 1950; Feldman et al. 1962; White and Magee 1962). Wang et al. (1950) ligated the pancreatic duct in rabbits to examine the subsequent histological changes and pancreatic function under the maximal stimulation of pancreozymin and secretin. They concluded that the pancreatic function was deteriorated to the extent of histological changes. As for the gastric function, the same correlation was also reported between parietal cells and acid secretion (Ragins et al. 1957; Marks et al. 1960). However, few literatures have been reported in which pancreatic parenchyma was quantitatively estimated and its correlation with 
exocrine function was studied. Only the report of Hansky et al. (1963) on the relationship between the canine pancreatic weight and function was comparable with the present study.

Since it was confirmed in the present study that the pancreas parenchyma without microscopical lesion occupied 90.47 to $93.97 \%$ of the total organ, pancreas with over $90 \%$ parenchyma might be considered as functionally normal. The fibrotic pancreas with $70.95 \%$ of parenchymal ratio showed the corresponding decrease in the flow of juice, outputs of bicarbonate and amylase. As for the residual parenchyma and its secretory function after pancreatoduodenectomy, a similar correlation was found when compared with the histologically normal remnant. Namely, the cases with $90.52,85.77$ and $39.46 \%$ of the corrected parenchymal ratios against Case 11 with normal histology showed considerably parallel depressions of their exocrine parameters. In the case with parenchyma of $2.26 \%$, exocrine secretion was extremely low and any numerical correspondence was not obtained. Since the residual parenchymal calls would be still scattered even in an extraordinarily fibrotic pancreas, measurement of parenchyma should be made in the overall organ as possible. As mentioned above, however, under the conditions of diffuse lesion it would be postulated that a quantitatively parallel correlation exists between pancreatic parenchyma and exocrine function in the endogenous stimulation of diet.

Since the so-called endogenous stimulation of diet in the present study was not uniform as the stimulant to each patient, the exogenous stimulation with secretin or pancreozymin, though in small numbers, was attempted to confirm the relationship between secretory activity and parenchyma. Under secretin infusion, a decrease in bicarbonate output was coincident with the parenchymal ratio in fibrotic pancreas. The parameters of exocrine function also tended to decrease in a parallel fashion within $\pm 10 \%$ divergency, and the more parenchymal reduction resulted in the less secretory outputs. Under pancreozymin stimulation the same tendency was observed. Although there might be arguments for and against that the dose of secretin or pancreozymin used in this study was not appropriate for submaximal stimulation comparable with each individual, it was suggested that the secretory output was affected by the histological changes and the volume of pancreas remnant even under the exogenous stimulation of secretin and/or pancreozymin.

The percent increase in enzyme secretion under pancreozymin stimulation was much higher in the non-resected pancreas than in the pancreatoduodenectomized. Interaction of neurological or endogenous factors during the exogenous infusion of stimulants should be taken into consideration. Further studies are required for this matter. Although some questions on the sequel of fibrotic pancreas or pancreatic remnant after pancreatoduodenectomy are still remained, the present study will show a clue for the rational treatment or substitution of enzymes after upper abdominal surgery. 


\section{References}

1) Annis, P. \& Hallenbeck, G.A. (1952) Effects of partial gastrectomy on canine pancreatic secretion. Surgery, 31, 512-527.

2) Caraway, W.T. (1959) A stable substrate for the determination of amylase in serum and other body fluid. Amer. J. clin. Path., 32, 97-99.

3) Elmslie, R.G., White, T.T. \& Magee, D.F. (1964) Observation of pancreatic fistula including a review of the literature. Ann. Surg., 160, 937-949.

4) Feldman, M., Dreiling, D.A., Paulino-Netto, A., Schaffner, F. \& Janowitz, H.D. (1962) Effect of D-L-ethionine on electrolyte secretion of the dog pancreas. Amer. $J$. Physiol., 205, 878-884.

5) Hansky, J., Tiscoria, O.M., Dreiling, D.A. \& Janowitz, H.D. (1963) Relationship between maximal secretory output and weight of the pancreas in the dog. Proc. Soc. exp. Biol. Med. (N.Y.), 114, 654-656.

6) Janowitz, H.D. \& Dreiling, D.A. (1962) The pancreatic secretion of fluid and electrolyte. In: Ciba Foundation Symposium on the Exocrine Pancreas, edited by A.V.S. de Reuck \& M.P. Cameron, Churchill, London, pp. 115-137.

7) Kaneko Y. (1971) Results of chemical balance study following various types of gastrectomy. Jap. J. Gastroenteral., 68, 940-949.

8) Lenninger, S.G., White, T.T. \& Magee, D.F. (1965) Studies of pancreatic juice in the proximal loop after Billroth II gastrectomy. Surg. Gynec. Obstet., 120, 507-510.

9) MacLean L.D., Perry, J.F., Kelly, W.D., Mosser, D.G., Mannick, A. \& Wangensteen, O.W. (1954) Nutrition following subtotal gastrectomy of four types. Surgery, 35, 705-718.

10) Marks, I.N., Komarow, S.A. \& Shay, H. (1960) Maximal acid secretory response to histamin and its relation to parietal cell mass in the dog. Amer. J. Physiol., 199, 579588.

11) Ragins, H., Evans, S.O., Jr., Dragstedt, L.R., II., Rigler, S.P. \& Dragstedt, L.R. (1957) Quantitative studies on the effect of gastric resection on the secretion of gastric juice. Arch. Surg., 74, 266-272.

12) Shiraso, M. (1973) A study of exocrine pancreatic function based on the pancreatic duct drainage. Jap. J. Gastroenterol., 68, 658-672.

13) Tournut, R. \& White, T.T. (1972) Water, electrolyte and protein secretion of the human exocrine pancreas in the early postoperative period. Surg. Gynec. Obstet., $135,17-21$.

14) Van Slyke, D.D., Stillman, E. \& Cullen, G.E. (1919) Studies of acidosis. XIII, A method for titrating the bicarbonate content of the plasma. J. biol. Chem., 33, 167178.

15) Wang, C.C., Wang, K.J. \& Grossman, M.I. (1950) Effect of ligation of the pancreatic duct upon the action of secretin and pancreozymin in rabbits with a correlated histological study. Amer. J. Physiol., 160, 115-121.

16) Weibel, E.R., Kistler, G.S. \& Scherle, W.F. (1966) Practical methods for morphometric cytology. J. Cell Biol., 30, 23-38.

17) White, T.T., Elmslie, R.G. \& Magee, D.F. (1963) The disappearing enzymes; A study of pancreatic enzymes in normal patients and after Billroth I and II gastric resections. Amer. J. Surg., 106, 307-316.

18) White, T.T. \& Magee, D.F. (1962) Recovery of pancreatic function after controlled duct obstruction. Surg. Gynec. Obstet., 114, 463-466. 